\title{
COPYRIGHT ACKNOWLEDGMENTS
}

Permission to reprint "The Need for a Religious Literary Criticism," which appeared in Religion and the Arts (Vol. 1, No. 1 [1996]: 124-50), has been granted by the author, Dennis Taylor, and by the Trustees of Boston College.

Permission to reprint short specified excerpts from Wallace Stevens's Opus Posthumous, The Letters of Wallace Stevens, The Necessary Angel, and The Palm at the End of the Mind has been granted by Alfred A. Knopf, Inc., and by Faber and Faber, Ltd.

Permission to print an adaptation of Professor Richard Kearney's "Poetry, Language, and Identity; A Note on Seamus Heaney," which originally appeared in The Dublin Journal (Winter 1986), has been granted by the author.

Excerpts from "East Coker," "Little Gidding," and "The Dry Salvages" in Four Quartets, copyright 1943 by T. S. Eliot and renewed by Esnie Valeris Eliot, have been reprinted with the permission of Harcourt, Brace and Company. Excerpts from Murder in the Cathedral by T. S. Eliot, copyright 1935 and renewed 1963 by T. S. Eliot have been reprinted with permission of the publisher.

A version of Stephen Fix's essay "Prayer, Poetry, and Paradise Lost: Samuel Johnson as Reader of Milton's Christian Epic" appeared in substantially similar form in the Journal of English Literary History 52 (1985): 649-681. Permission to reuse material from that essay has been granted by the editors of $E L H$.

Permission to reprint specified excerpts from the Collected Poems 
of Stevie Smith has been granted by New Directions Publishing Corp. and by Professor James MacGibbon.

Special thanks to Professor J. Robert Barth, S.J., for the cover photograph of Tintern Abbey. 
